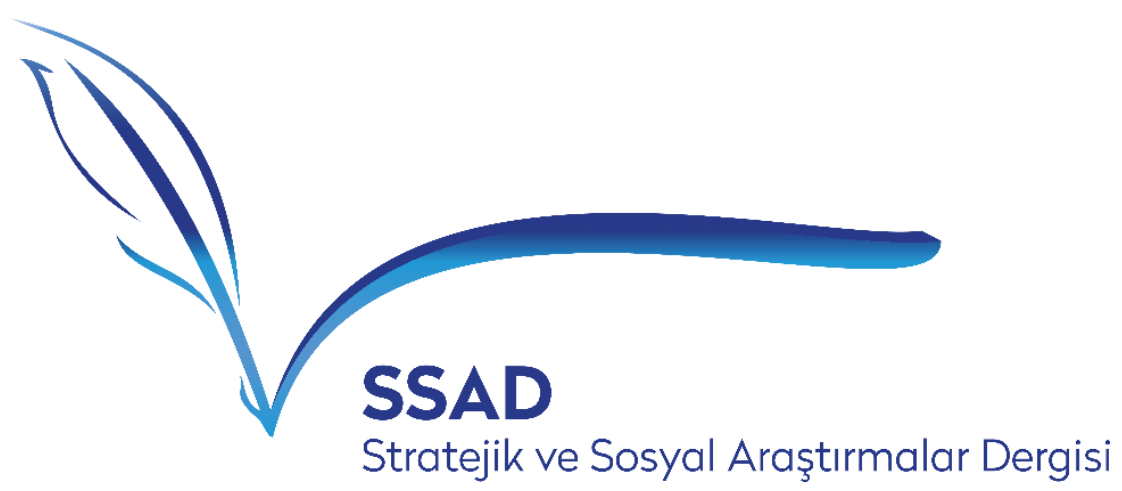

ISSN: 2587-2621

Volume 3 Issue 1, March 2019

Makale Gönderim Tarihi: 04.12.2018

Makale Kabul Tarihi: 24.02.2019

\title{
TURKISH STUDENTS' ATTITUDES AND INTENTIONS TOWARDS WHISTLEBLOWING
}

\section{Türk Öğrencilerin Meşru İhbarcılı̆̆a Yönelik Tutum ve Niyetleri}

\author{
A. Barış BARAZ \\ Anadolu University, Turkey \\ bbaraz@gmail.com \\ Hacer ȘiviL \\ Anadolu University, Turkey \\ hsivil@hotmail.com
}

\begin{abstract}
The development of information and communication technologies has led to significant changes in business and social life. Both communication and business practices have completely changed. Nowadays, the ones without English skills, computer literacy or the ability to use internet technologies are almost nonexistent in the business world. However, although new technologies have brought about new opportunities, they have also given rise to some new problems, among which is the whistleblowing concept translated as mesru ihbarcilik into Turkish. The subject of the study consists of how whistleblowing behavior is perceived. The behavior can be defined as reporting immoral or inappropriate behaviors within an organization to the ones in authority by employees. In particular, the study analyzes the differences between young people and the elderly, in other words, Gen X and Gen Y's attitude and intention towards whistleblowing. In order to access and analyze the data of a large number of students, the opinions of the students from the 'Business Administration Department' at Anadolu University, considered as 'entrepreneur and executive candidates for the future' were selected. To define the relationship between two or more variables and learn the cause and effect relationship, the correlational research method, one of the quantitative research methods, was used. Purposive sampling technique, which tries to explain natural and social events or phenomena, was applied. To figure out the students' whistleblowing attitude and intention, 'Whistleblowing as Planned Behavior' survey, based on Theory of Planned Behavior by Ajzen (1991) and developed by Park and Blenkinsopp (2009), was used. The results were evaluated according to the data gathered from 2683 students who are prospective candidates for future managerial and entrepreneurial positions. As a result, it was found out that Gen Y students' intention towards whistleblowing is higher due to socio-political and economic experiences they have undergone. Overall Gen Ys are more competent than Gen Xs in terms of online whistleblowing, they are more intensely internalizing electronic business processes.
\end{abstract}

Keywords: Whistleblowing, Generations, Theory og planned behaviour 
Öz: Bilgi ve iletişim teknolojilerinin gelişmesi iş hayatında ve sosyal hayatta önemli değişimlere yol açmıştır. Sözgelimi insanların haberleşmesi tamamen farklı araçlar kullanılarak yapılmaya başlamıştır. İş yapma yöntemleri değişmiştir. Artık bilgisayar okuryazarı olmayan, internet teknolojilerini kullanamayan hatta İngilizce bilmeyen insanların çalışma hayatında yeri neredeyse yoktur. Yeni teknolojiler beraberinde yeni firsatları ve yeni sorunları da beraberinde getirmiştir. Meşru ihbarcılık (Whistleblowing) olarak Türkçe'ye çevirdiğimiz kavram da bu yeni konular arasında yer almaktadır. Örgüt içindeki uygunsuz ve etik olmayan durumların çalışanlar tarafından yetkililere bildirilmesi olarak tanımlayabileceğimiz "meşru ihbarcılık" davranışının nasıl algılandığı bu araştırmanın konusunu oluşturmaktadır. Özellikle gençlerin ve yaşlıların, başka bir deyişle X ve Y kuşağı olarak ayrılan iki farklı kuşağın meşru ihbarcılık tutum ve niyetlerini arasında ne gibi farklar olduğu araştırmada irdelenmektedir. Daha çok sayıda öğrencinin verilerine erişip analiz edebilmek için Açıöğgretim Fakültesi öğrencileri üzerine yürütülen araştırmada "geleceğin girişimci ve yönetici adayları" olarak değerlendirdiğimiz "İşletme" bölümü öğrencilerinin görüşleri seçilmiştir. İki veya daha fazla değişken arasındaki neden sonuç ilişkilerini analiz etmek amacıyla nicel araştırma yöntemlerinden ilişkisel/korelasyonel araştırma yöntemi kullanılmıştır. Öğrencilerin meşru ihbarcılık tutum ve niyetlerini ortaya çıkarabilmek için Ajzen (1991)'in Theory of Planned Behavior - Planlanmış Davranış Teorisi (PDT)'ne göre Park ve Blenkinsopp (2009)'un geliştirdiği “Whistleblowing as Planned Behavior” ölçeği kullanılmıştır. 2683 yönetici ve girişimci adayı öğrenciden elde edilen veriler analize tabi tutulmuş ve çıkan sonuçlar değerlendirilmiştir. Sonuç olarak bu iki kohortun deneyimlediği sosyopolitik ve ekonomik sürece bağlı olarak, Y kuşağ öğrencilerin meşru ihbarcılık niyetleri X kuşağı öğrencilere göre yüksek çıkmıştır. Y kuşağının bu davranışı meşru ihbarcılığın elektronik ortamlarda yapılabilmesi ve genç kuşağın elektronik iş süreçlerini daha yaygın içselleştirmesi ile açıklanabilir.

Anahtar Kelimeler: Bilgi Uçurma, Nesil, Planlanmış davranış teorisi

\section{Introduction}

As it is known, since the term management got a scientific feature in the 1900s, the value given to employees has significantly changed. Employees, once seen as a piece or part of a machine especially by Frederick E. Taylor, Henry Fayol and Max Weber, the pioneers of Classical Approaches, are now an invaluable element of organizations. Now, thanks to technological advancements, life span is longer, so is the tenure in an organization. As a result, people from different generations or cohorts, who have experienced similar external events, are able to work together, yet each one has their own values, attitudes, ambitions, trends, and codes that may lead to some conflicts in the conduct of business behavior. Thus, their perception of whistleblowing may be different. Some people think that whistleblowers are not loyal members of an organization; like in the Snowden's case, many called him 'traitor'. Rat, tattletale, fink, troublemaker, and turncoat are other names used to humiliate whistleblowers. However, Jeffrey Wigand (2011), the former vice president of research and development at the Brown \& Williamson Tobacco $(\mathrm{B} \& \mathrm{~W})$ and whistleblower, is not happy with the word whistleblowers since it is laden with negative connotations. That is why he suggests a new phrase: person of conscience (Devine \& Maassarani, 2011). Similarly, Grant sees them as heroes or as the saints of secular culture and expresesses his dissatisfaction with the term (Grant, 2002: 391).

Organizations might apply to some immoral, illegal or illegitimate practices to gain competitive advantages, to improve efficiency and effectiveness or to have some personal benefits. It is highly possible that malpractices conducted by an organization are known by its workers. Obviously, without disclosures made by whistleblowers, the results of cases like Enron in the USA, Parmalat in Italy Ahold in Holland, Kanebo in Japan, and Roche in Turkey would have been more devastating. Those examples clearly depict that an organization all around the world is prone to any kind of illegal, immoral, or illegitimate acts when the conditions are deliberatively prepared. Governments have been trying hard to prevent workers and organizations from illegal, immoral, or illegitimate involvements, yet it is mostly whistleblowers who bring any kind of wrongdoing/misconduct/malpractice to light.

There are auditors that can be bought, laws that can be violated, and shareholders/stakeholders that can be cheated. However, an organization, whether governmental, private or non-profit, is 
responsible for its employees, shareholders, stakeholders, customers, competitors, suppliers, environment, governments, and society's well-being in many aspects. When any given party is exploited, and it is observed, it should be fixed immediately. Otherwise, destructive effects are inevitable. The tragedy involving NASA's Challenger space shuttle proves that the firm Morton Thiokol, which contracted with NASA to design and build the solid rocket boosters, had ignored the warnings of the engineer Roger Boisjoly and led 7 crew members to die in front of the public, which also tarnished NASA's reputation (Devine \& Maassarani, 2011:31; Miceli \& Near, 1992:6). Similar events especially like in the Snowden case in the corporate governance bring about some questions in terms of people's attitudes and intentions towards whistleblowing.

In this study, some basic terms related to whistleblowing behavior and generations will be discussed. It is aimed to prove whether the whistleblowing attitude and intention of students who have work experience and who are from Gen X and Gen Y differ or not in Turkish setting.

\section{WHISTLEBLOWING}

Among many definitions, the most referred one is made by Miceli \& Near: whistleblowing is defined as the disclosure by organization members (former or current) of illegal, immoral, or illegitimate practices under the control of their employers, to persons or organizations that may be able to affect action. For an act of whistleblowing to happen, it must involve at least four elements (Miceli \& Near, 1985:2-4):

- The whistleblower: As understood, whistleblowers must be either a former or current member of the organization without the authority to stop the wrongdoing or whose actions are under the control of the organization even though their jobs require blowing the whistle as in the cases of internal auditors and ombudsmen.

- The whistleblowing act: It is giving of the information that harms third parties or public interest.

- The complaint receiver: It is the person or agency that the complaint is voiced at. It may be within the organization or outside. Some researchers claim that only external whistleblowing is the true case whistleblowing while some others say it may be lodged internally, externally or the combination of both.

- The complaint: Any organization ranging from large, small, public, private, young to old may be complained about.

It is not known when the term 'whistleblower' originated, but its origin may go back to the 1930s, and it may refer to an official on a playing field, such as a football referee, who can blow the whistle to stop an action (Miceli \& Near, 1992:15; Jubb, 1999:77). The term "whistleblowing" was first used in 1963 in the USA in documents concerning internal security risks at a Senate committee. As a word, it means the police blowing the whistle against a criminal to prevent a crime (Hersh, 2002:243).

The term is relatively new in an organizational context. Only the word 'to whistle' was described to mean to whisper or to tell something secretly in the Oxford English Dictionary, but the words 'whistleblowing' or 'whistleblower'. In a similar vein, the 1976 edition of Webster's Third New International Dictionary of the English Language only listed the meaning of 'to whistle' that meant to signal as if by signaling. Eventually, a 1986 supplement to the Oxford English Dictionary used 'whistleblowing' as to ring an activity to a sharp conclusion, which means more or less the same today. In an organizational context, the very first usage goes back to 1971, when a letter to the editor of a journal was sent to criticize whistleblowing behavior. In the same year, the chairman of the board of General Motors warned against whistleblowing claiming that some 
enemies encouraged employees to be disloyal to create suspicion and disharmony. However, in 1972, soon after, a consumer advocate Ralph Nader used the same word from a prosocial point of view and claimed that if employees believed the organization they served for was involved in corrupt, illegal, fraudulent or harmful activity, they should blow whistle since the public interest was more important than the interest of the organization (Vandekerckhove, 2006:7-8).

Although 'whistleblowing' and 'whistleblower' terms became widespread in the $20^{\text {th }}$ century, the first event took place in the 1700s in the American Navy. Feeling dissatisfied with the commodore's incompetence and poor management decisions, the captain, John Grannis, and some crew members wanted the removal of Commodore Hopkins, head of the Continental Navy. When it was proved that the commodore was ineffective, he was fired, which improved conditions and caused the Continental Congress to pass the Whistleblower Law in 1778. This law wanted anyone to report any kinds of misconduct, frauds, or misdemeanors to Congress (Gaudet, 2016:4$5)$.

It can be claimed that whistleblowers have always existed in politics and business life all around the world. Since its establishment, the Ottoman Empire tried to get prior notice about the neighboring states to prevent any possible threats toward the throne by means of spies. When we glance at the Ottoman Empire, it is seen that Murad II appointed someone to get information about the Hungarians during the Battle of Kosovo in 1448. Similarly, Yavuz Sultan Selim sent spies to Iran during Çaldıran Seferi in 1514 and to Egypt before Misır Seferi (1516-1518) to get information about their armies and their secret relations posed to attack the Ottoman Empire. It is also said that Mahmud II set up a spy network to surpass the opponents who were dissatisfied with the abolishment of Yeniçeri Ocağı- Guild of Janissaries in 1827. The Empire was so massive and power struggle was so strong that the sultans appointed spies not only outside the Empire but also inside to take control of the deeds of governors, people in authority, or even ordinary people (Beyhan, 1999:65-67).

We frequently come across the word jurnal- which originated from the French word journalmeaning secret information reported to the sultans. Though the sultans were frequently informed by means of jurnals, these jurnals lost their meaning in time because they included trivial things from daily talks about the throne to wishes to get a job and used as a threat to discredit anyone unjustly (Hür, 2015).

After his uncle Abdülaziz and his brother Murat V were dethroned, Abdülhamid II was brought to the throne on some conditions in 1876 when the Empire was getting weaker and some people were getting stronger, which adversely affected Abdülhamid II. Feeling lonely and insecure, the Sultan tried to gain absolute power and made some regulations. As a result, Hafiye Teşkilat1- The Secret Service- was set up (1876-1909). However, anyone craving for status, authority, reward, money, or reputation started to bombard the Sultan with fake jurnals about anyone they did not like even though they were not hired for the Secret Service. Moreover, there was competition within the Secret Service itself (Haydaroğlu, 1997: 109-110; Beyhan, 1999:70-71). As a result, like in many countries including the USA, in Turkey, the terms whistleblowing and whistleblowers have negative connotations when they are translated into Turkish.

We come across similar examples that corroborate the negative connotations of the terms; whistleblowing and whistleblowers. In his article 'The Public Interest' issued in 1981, the management expert Drucker clearly states that he is against whistleblowing by stating "it is not quite irrelevant that the only societies in Western history that encouraged informers were bloody and infamous tyrannies". Drucker dispraises whistleblowing behavior and whistleblowers by giving examples from history. He says that whistleblowers who were applied in many cases; in Tiberius and Nero in Rome, for the Inquisition in Spain during the reign of Philip II, and in Russia during the reign of Stalin, had devastating effects. For him, under such a regime, no mutual trust, 
no interdependencies, and no ethics are possible (Orr, 2001:4). Similiarly, some other scholars like Clinard (1983), Heller (1983), and Weinstein (1979) believe that whistleblowers pose a great threat to an organization since they give damage to the reputation, loyalty, and performance. However, some like Ewing (1983) think just the opposite (Miceli \& Near, 1985:1).

As it is seen, there is no consensus on the perception or meaning of whistleblowing. For instance; Turkish researchers Gerçek (2005), Celep \& Konaklı (2012) and Baltac1 (2017) used bilgi uçurma, Taş \& Antalyalı (2015) used izharcllık, Candan \& Kaya (2015) and Yürür \& Nart, (2016) used ihbar/ihbarcılık, Mercan et al. (2012), Arslan \& Kayalar (2017), Bayrakçı \& Kayalar (2016) used if̧̧a. On the other hand, many Turkish researchers like Esen \& Kaplan (2012, Çiğdem (2013), Özler vd. (2010), Kördöve (2017), Sayğan (2011), and Aktan (2006) prefer to use the original term to avoid misunderstanding or to take no side.

However, whistleblowing is not the same as informing because a whistleblower reveals the information in the hope that the recipient will do something to stop the wrongdoing. That is, whistleblowing should have a definite goal to stop an action or to prevent a similar type of malpractice in the future (Near \& Marcia, 1996: 510).

According to Sayğan and Bedük, employees within organizations should feel responsible for the public good and should not overlook any inappropriate practices when they have observed them, so they should make sure of the whole process from safety of the money invested in the bank to the water delivered hygienically (Sayğan \& Bedük, 2013). That is, things like violation including, but not limited to violation of the rights of shareholders and stakeholders, the production and marketing of food unsuitable for public health, human rights violations, illegal employment, employment without social and financial rights, tax evasion, harassment, and violence might lead to whistleblowing. As for Baltac1 (2017), whistleblowing is done by conscious employees who are aware of the laws and socially accepted ethical judgments and illegitimate actions and behaviors (Baltac1, 2017: 397).

\subsection{Whistleblowing Process}

There are several steps/phases that lead to whistleblowing behavior (Miceli , Near, \& Schwenk, 1991:115; Miceli \& Dozier, 1985:831; Miceli \& Near, 1985:4-5):

- Awareness of the wrongdoing: The observer decides whether the activity is illegal, immoral, illegitimate or not. The degree of awareness depends on the observers' position or their personal, professional, or organizational standards of ethics.

- Assessment of the seriousness of the wrongdoing: When the observer makes sure that whistleblowing is the only solution to terminate the wrongful act, s/he is more likely to do it. Moreover, the observers' characteristics, financial, and emotional support help him/her decide what to do. Besides, it might be costly in many aspects like being excluded by colleagues, or the organization might retaliate against the whistleblower.

- Responsibility for taking action

- Assessment of the consequences. 


\subsubsection{Types of whistleblowing}

When an employee observes an inappropriate behavior, s/he might prefer to remain silent, report it to someone within the organization, or report it ouside the organization (Erkmen, 2014). Studies show that classifications are mostly internal and external, but Park and his colleagues) in Figure 2 propose a typology of whistleblowing based on three dimensions, which includes not only internal versus external whistleblowing approaches as in the previous studies, but also identified versus anonymous and formal versus informal approaches. That is, each dimension represents a choice for the employee. Accordingly, provided that an organization has a formal organization protocol for reporting misdeeds, the observer might choose to follow it or may prefer to talk to someone s/he trusts about the wrongdoing. The observer might use his/her real name or keep it anonymous. The observer might also report the wrongdoing inside the organization or outside the organization for various reasons (Park, et al, 2008: 930).

Figure 1. A Typology of Whistleblowing (Park, et al, 2008: 930)

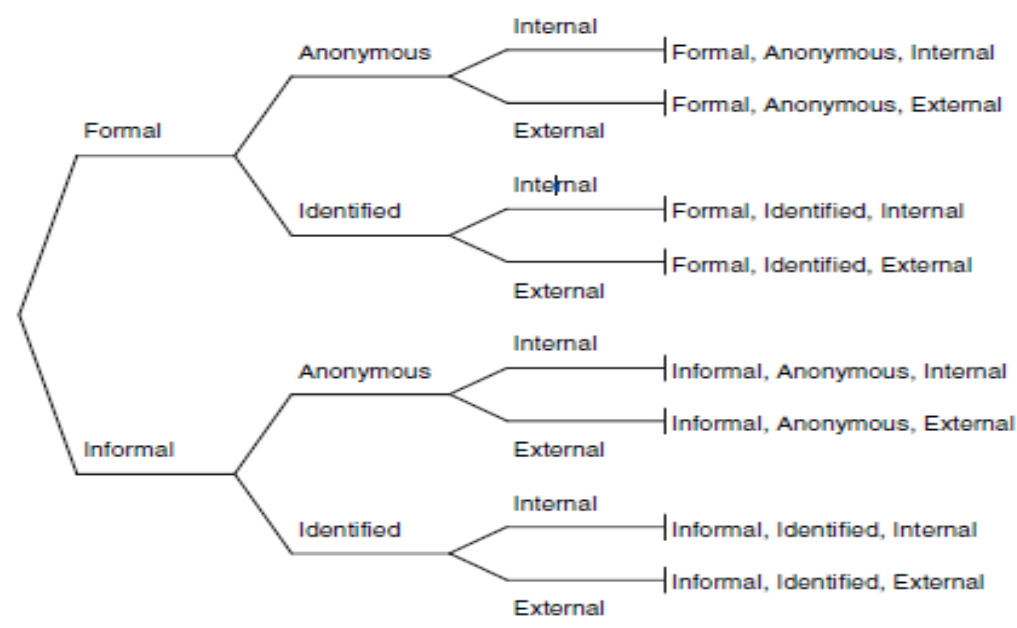

Reporting a malpractice inside the organizationis called internal whistleblowing. Some ethicists like Bowie (1982) and De George (1986) claim that using internal channels is moral. However, Near and Miceli (1987) and Farell and Petersen (1982) believe that whistleblowing is not simply informing; thus, using internal channels cannot be defined as whistleblowing. Observers might be affected by statutes because some state statutes protect whistleblowers when they use the internal channels while some protect them when external channels are used (Near, et al, 2004: 211). Many researchers believe that it is important to encourage employees to choose the internal channels; thus, the organization will be saved from losing face.

Reporting of a wrongdoing outside the organization that is believed to have the necessary power to correct the wrongdoing is external whistleblowing. As for De George (2010), external whistleblowing can be considered as morally permissible if an organization's policy or product gives harm to employees or the public, if employees first report their concern(s) to their immediate supervisors, and if nothing about the concern(s) is done (Hoffman \& Schwartz, 2015: 773). As it is known, many internal whistleblowers continue their complaints to external parties, so internal and external whistleblowing are considered to be related (Near \& Marcia, 1996: 509). As for Hoffman and Schwartz, if an organization does not have a written anti-retaliation policy 
against whistleblowing, the employees are not obligated to blow the whistle internally (Hoffman \& Schwartz, 2015: 775).

\subsection{Whistleblowing as a Prosocial Behavior}

In organizational settings, prosocial behavior is a behavior which is performed by a member of an organization, directed toward an individual, group, or organization the member interacts with, and performed with the intention of promoting the welfare of the individual, group, or organization toward which it is directed. It includes in-role or extra-role behavior, so it is more inclusive than organizational citizenship behavior (Brief \& Motowidlo, 1986: 711; Seifert, 2006: 20).

As stated above, whistleblowers may threaten an organization's authority structure and functioning. To set an example, the US Director of National Intelligence, James Clapper, admitted that they have experienced profound damage and lost critical foreign intelligence collection source after Snowden's disclosure (Gaudet, 2016). However, by means of whistleblowers, organizations have the chance to correct practices that may harm organization members, customers or clients (Miceli \& Near, 1985: 4, Dozier \& Miceli, 1985: 823), which brings to the mind prosocial behavior.

There are some common codes of ethics that are written neither in social nor business life. Yet, all organizations are responsible for their internal environment that consists of their employeees, share/stockholders and external environment which includes the government, nature, and society in general (Aktan, 2008: 103). That is why responsibilities are more than altruism.

Although altruism, in which an actor performs the behavior voluntarily without expecting to receive any rewards in return, is a kind of prosocial behavior, some scholars like Dozier and Miceli (1985), Miceli and Near (1988, 1992), and Brief and Motowidle (1986) do not see whistleblowing as an act of pure altruism. Leeds states that if an act is only for the sake of altruism, it should involve the following elements: There should not be any personal gains, it should be on a volunteer basis, and the action should be regarded as positive and good (Leeds, 1963: 230-231). Yet, regarding personal gains, although many whistleblowers have experienced employer retailation, they may also seek some personal benefits like workplace safety that directly affects them. In terms of volunteer, some jobs like auditing require whistleblowing. As for outcomes, a whistleblowing act may lead to mixed outcomes. Thus, it is not entirely altruistic, for it involves selfish (egoistic) and unselfish (altruistic) motives (Dozier \& Miceli, 1985: 823-825).

To set an example, in the 1960s, Ford tried to gain a competitive advantage over Japanese cars and manufactured a lighter and cheaper car, Pinto, in a short time. However, its defective fuel tank did not pass the safety test. That meant the risk of catching fire in the event of a rear-end collision. Although fuel tank standard was not included in the current regulation, Ford engineers knew that this test was the part of the standard safety procedure. Ford refused to take action against it and continued to produce and sell the car until 1978. During this time, they did not inform the customers about the possible risks, either (DeGeorge, 1999: 240-242). In this case, one can argue that a Ford employee or manager would only have been morally permitted to blow the whistle externally but would not have been morally obligated to do so (Hoffman \& Schwartz, 2015: 778).

\subsection{Importance of Whistleblowing}

Since the term "management" does not only focus on effectiveness and efficieny as it used to be, a new term 'corporate governance' is preferred to highlight the importance of an organization's 
responsiblity towards its internal and external environment. Within this framework, corporate governance is a system in which companies are managed and inspected. Managers are obliged to manage the company, and stakeholders are obliged to appoint appropriate managers and auditors. The most fundamental task of corporate governance is the accountability of its stakeholders since managers are the agents. As a result, the welfare of the company means the welfare of the stakeholders. For this reason, it is an important tool for a company to empower its business governance strategy when business practices are notified of a wrong application. Thus, the employer plays an active role in creating a safe working environment by protecting the profit and reputation of the company.

The concept of corporate governance has become popular with big conglomerates such as Enron and WorldCom, as the scandals, financial crises, globalization and privatization concepts come to the fore. Institutional governance, which holds responsibility for stakeholders, plays an important role in controlling the authority of the owner of the power, ensuring transparency and clarifying responsibilities, thus protecting all kinds of stakeholders' rights, creating an environment of trust for investors, enhancing corporate reputation and value is a must (Ağlargöz, 2013: 147-149).

According to the results of KPMG's Fraud Survey 2003, 75\% of participating companies experienced fraud in the previous twelve months in the United States (KPMG: 2003). In the 2004, Report to the Nation on Occupational Fraud and Abuse, the Association of Certified Fraud Examiners (ACFE) estimated that the typical U.S. organization loses $6 \%$ of its annual revenues to fraud, which means it was approximately $\$ 660$ billion loss in the U.S. Gross Domestic Product (GDP) for 2003 (ACFE, 2004). Similarly, based on the 2016 report that covered January 2014 and October 2015 and prepared by ACFE, the loss in 2016 was huge. The report contains an analysis of 2410 cases of occupational fraud in 144 countries. As a result, it was estimated that the typical organization lost 5\% of its revenues in a given year as a result of fraud. 2,410 cases of occupational fraud, 15 of which were from Turkey, in this study exceeding $\$ 6.3$ billion, with an average loss per case of $\$ 2.7$ million. To illustrate the magnitude of this estimate, applying this percentage to the 2014 estimated Gross World Product of \$74.16 trillion results in a projected potential total fraud loss of up to $\$ 3.7$ trillion worldwide. However, it does not include indirect costs, such as reputational harm or loss of stakeholder relationships, so the true total loss represented by these cases was likely much higher. In the report, it is also stated $30.1 \%$ of cases were detected by means of whistleblowing, the most common method (ACFE, 2016).

The reports mentioned above prove that many corporations are prone to wrongdoing, and lack of effective internal auditing methods paves the way for it. Vandekerckhove specifies two reasons for an organization's need for whistleblowers: More employees will be involved in decision making process, which will continuously help the organization to be informed about misdeeds, and the public will be made aware of facts (Vandekerckhove, 2006: 226).

As for Miceli and Near, by means of whistleblowing, investors are warned of financial wrongdoing; taxpayers may benefit from increased services or lower taxes; organizations have the chance to monitor themselves; society benefits from the activation of the codes and the avoidance of organizational wrongdoing (Miceli \& Near, 1992: 14).

In his article named We Need More Whistleblowers, Verschoor reminds us three women- Sherron Watkins, who reported the fraudulent financial reporting of Enron, Cynthia Cooper, who did the same at WorldCom, and Coleen Rowley, who informed the FBI prior to the September 11, 2001 terrorist attacks -honored as Persons of the Year by the Time (Verschoor, 2010). Though they were honored, they had experienced some sorts of retaliations, which deter observers. 


\subsection{Legitimating Whistleblowing}

In general, people not only in business life but also in social life are getting used the term whistleblowing by means of various channels. Some are as follows:

1. Hotlines of the news channels and newspapers, social networking sites like Twitter, whatsApp, Instagram and Facebook make whistleblowing more possible. Besides, some companies want to make sure that employees respect the public, thus there is a sign saying 'If I have made a mistake, call the following number'. Furthermore, some webpages provide online consultancy as stated below.

- National Whistleblower Center (NWC): The NWC, which has been serving since 1988 and has defined itself as a non-profit, tax-exempt and neutral institution, describes how whistleblowers can protect themselves with a booklet on their official website. The NWC's lawyers provide consulting services to the Congress under laws such as the Dodd-Frank Act, which protects consumer rights, the Sarbanes-Oxley Act and the Detention and Protection Improvement Act (NWC).

- British Standard Institution (BSI): The BSI Group has a confidential "hotline" telephone service which is operated independently by Expolink, an external provider; this allows employees and non-BSI individuals to report anonymously inappropriate behaviors when they believe they violate the BSI Code of Business Conduct. Notifications can be made 24/7 by calling the toll-free phone line (BSI, 2004).

- Prime Ministry Communication Center (BIMER): It is an effective public relations practice initiated in 2006 in Turkey. Citizens are allowed to make a complaint, a wish, or a proposal. However, as stated on the web page, the notice should not be defamatory. Otherwise, criminal procedure is applied to the person in accordance with Article 267 of Turkish Penal Code (TCK) (BİMER).

- Presidency Communication Center (CIMER): Like BIMMER, it evaluates citizens' questions within 30 days in Turkey (CIMER).

2. Institutional Policies: To facilitate whistleblowing for the employees who do not feel safe, institutional policies should be implemented. The complaint might be made to an ombudsman, via hotlines, and the like, yet it should be warranted that employees will not be retaliated. Similarly, appeal forms or boxes can be made available in the organization.

In recent years, it has been observed that regulations about notification in organizational codes of ethics have begun to take place in Turkey. For example, in Doğuş Otomotiv's "Ethics Code", it appears that there are sections about the notification mechanism and the protection. Apart from the company's code of ethics, "bribery and anti-corruption policy" and "ethics hotline" regulations guarantee that whistleblowers will be protected (Çiftçi, 2017: 150).

3. Printed Resources: Studies in this field, presentations and books about whistleblowing increase awarenes. For instance, the book called Whistleblowing and Organizational Social Responsibility by Wim Vandekerckhove (2006) both refers to the process of legalization of whistleblowing and presents it as an ethical evaluation (Danışman, 2012: 227). 
4. Media and Information Technologies: The developments in written and visual media make it available for everyone to obtain the news about all kinds of whistleblowing. WikiLeaks-like internet sites address social concerns about notifications, and notifications are positively influencing the perception of the community (Çiftçi, 2017: 149).

5. Laws: Laws related to whistleblowing are implemented in many countries. Among them Sarbaney Oxley Act (SOX) is one of the most important ones. Cases like Enron, WorldCom, Xerox, and Swiss Air proved that such corporations became unsuccessful due to unserious accounting records and management practices. As a result, in 2002 SOX made some regulations for corporate governance which were put into practice in 2002. They are summaried below (Kurumsal Yönetim, 2017: 74):

- Public Oversight Accounting Board was established.

- Auditors' responsibilities were regulated; they were prohibited from having non-audit services, and criminal provisions were introduced in the event that the auditors mislead.

- Reporting misdeeds in companies was made compulsory, and the protection mechanism for whistleblowers was legally secured.

- Managers were banned from taking personal loans from the company.

- The members of the company's board of directors, including other CEOs and CFOs, were held accountable for the misappropriation of company accounts, and it was accepted that their rights and interests could be confiscated.

There are some laws in Turkey, too that give rights to whistleblowers to gain information, to give a complaint petition, to give anonymous statements, to get rewards, and the like as stated in the laws 5178, 5237, 5726, and 2863 (Uğur, 2013).

6. Intergovernmental Bodies and Whistleblowing Policies: The issue of whistleblowing is important for intergovernmental bodies such as the Organization for Economic Cooperation and Development (OECD), the European Commission and the Council of Europe. These bodies have investigated the legal applications of whistleblowing in different countries. As a result of some conventions, the Criminal Law Convention on Corruption and the Civil Law Convention on Corruption were signed by 14 countries including Turkey in 2003 (Vandekerckhove, (2006: 270- 274).

In quest for finding out how the best management in the globalizing economy should be, the OECD published a guideline under the name of 'Corporate Governance Principles' in 1999. In this respect, the Turkish Industry and Business Association (TUSIAD) published the corporate governance principles to be followed in Turkey (Tekin, 2003). Those principles consist of an efficient legal and regulatory framework for state owned enterprises and employers, shareholders to be subject to fair treatment, relations with the stakeholders, transparency and making explanations to the public, responsibilities of the board of directors of state owned enterprises (TÜSİAD). 


\section{GENERATIONS}

In his study, Gaudet refers to a survey about Edward Snowden, who leaked secret documents of National Security Administration (NSA) to the Guardian, conducted by the Pew Research Center. Interestingly, Gen Ys were significantly more supportive of Snowden's leak than those in older generations (Gaudet, 2016). If there are perceptional differences among generations in Turkish business, organizations should keep these differences in mind while employing them.

Generations are categorized differently in different sources. It is mainly because of people living in different places and being exposed to different events. As Mannheim $(1928 ; 1952)$ stated, generations are not a group of people who live in a specific period of time but are groups of people who have mutual experiences and backgrounds. In this respect, not all people born in the same period have similar backgrounds, so they may not have the characteristics of the same generation. Thus, it can be asserted that a generation is a group of people who are born almost in the same time period, and whose values, attitudes and life styles are developed in a similar way by specific events within that period.

In this research, the categorization of generations is done as Ayhun (2013), Kuran (2012), Seçkin (2000), Şenbir (2004), Benison (2008) Altuntuğ (2012), Tolbize (2008) Karp (2002); Mengi (2009, Kilıç (2012), Habib (2013), Çatalkaya (2008), Susuz, (2012), Çağ (2012), İzmirlioğlu (2008), Mesutoğlu (2013), and Topçuoğlu (2007) have done. Thus, 1925-1945 is called Silent Generation; 1946-1964 is called Baby Boomers; 1965-1979 is Gen X; 1980-1999 is Gen Y, 2000+ is called M (or Z) (Arslan \& Staub, 2015).

Generations in Turkey are shaped based on some certain event that has had an effect and happened in Turkey. Thus, these important events will be referred to explain their characteristics.

\subsection{Silent Generation (1925-1945)}

In Turkey, the members of this generation were born after the devastating effects of World War I (1914-1918) and the War of Independence (1919-1922). They witnessed a major change of regime; namely, the Ottoman Empire that collapsed and establishment of the Republic of Turkey and many subsequent revolutions and reforms. It is certain that the members of this generation and their parents had to deal with a number of difficulties. Moreover, the level of literacy of the people, the communication technologies in the period and the economic situation were not good. Many things including national pact, capitulations, and minority rights were sorted out. Though the country was suffering from destruction, famine and man power, it tried hard to establish 'peace at home peace in the world' notion. Thus, even though it did not take part in World War II (19291945), it was still adversely affected. The government tried to strengthen the army, so labor was lost in production, which decreased agricultural productivity. Consumption and distribution were completely under the state control with the National Protection Act of January 18, 1940, but this increased the black market and poverty and made a class even richer (Bülbül, 2005: 44-45).

To sum up, the members of Silent Generation, also called Veterans, are today's grandparents who are much more frugal. They give importance to hierarchy.

\subsection{Baby Boomers (1946-1964)}

In Turkey, Democratic Party (DP) was set up in 1946 and multi parties era started. However, when DP was in power in the 1950s, the Turkish people were under pressure and aimed at ending the oppression and totalitarian regime. They witnessed the first military coup on May 27, 1960 as 
well as the prosecution of the then Prime Minister Adnan Menderes (Doğan, 2009). For this generation, who sees non-democratic practices against freedom and independence in the country, growth, prosperity, goods and services are invaluable. They are the architects of Gen Y.

\subsection{Gen X (1965-1979)}

Petroleum crises, economic straits, 68 generations, university events, left-right conflict and television are the most important events of the period. In Turkey, women began to participate in the labor force intensively. People started to have fewer children to live better. They focused more on the money, and individualism became important (Mengi, 2003).

Due to the fact that both parents were in the working life, children of this age had to learn to take care of themselves. They had to figure out many things like how to go to school and what to eat. Since they were on their own after school, they had to carry their keys with them; therefore, these children were called latchkey kids (Stroman \& Duff, 2012: 76).

Xers, Postboomers, the Shadow Generation, Thirtheenth, Thirteeners, Twenty-Somethings, MTV Generation, Generation Next, Baby Busters Slackers, Generation 2000, or simpy Gen X have played a great role in shaping today's technology and the perception towards work because they give importance to life-work balance.

\subsection{Gen Y (1980-1999)}

Gen Ys were born during the events that affected political and social balance both in Turkey and in the world. The Gulf War, the Iraq War, the Internet, the January 24 Decisions, the end of the Soviet Union in 1991, the fall of the Berlin Wall in 1989 were some of the most important events that made contributions to the characteristics of this generation. Since they did not witness any economic or social insecurity that had taken place before the 1980s, they think whatever we have now has always been available (Toruntay, 2011: 75-81).

The January 24th Decisions of the 1980s took place during the reign of Turgut Özal, the 8th President of the Republic of Turkey, and played an important role in shaping the perspective of the Gen Y. Özal expressed the importance of innovation and the need to move forward at a faster pace in order to catch up with the change initiated 200 years ago by the western world. He also stated that the Ottoman economy which was based on agriculture was not able to keep up with the pace of the western world, which led to the black market. Özal referred to the importance of three things at every opportunity. The first two were the freedom of opinion and religionconscience, which were signs of democracy and tolerance. The last one was the freedom of enterprise, which was possible by means of free market economy. Özal's decisions, known as the January 24th Decisions, contributed significantly to the adoption and implementation of a range of economic measures (Aktan, 1996).

Members of Gen Y, who grew up with the concepts of freedom, equality, transparency and competition, do not usually prefer to leave home and enjoy being with their families unlike their parents (Kuran, 2013).

Me Generation/Generation Me/GenMe, nGen, iGen, Millennials/Millennium Generation, Nexters/Nexter, Generation www, the Digital Generation, Generation E, Echo Boomers, N-Gens, Baby Boomlet, Internet/ Nintendo Generation/ MySpace Generation/ iPod/iGeneration/ Gamer Generation, Generation Why are some of the names given to Gen Y. 
Kuran (2013) categorized generations and their characteristics in Turkey as follows (Kuran, 2013):

Table 1. Characteristics of Generations in Turkey

\begin{tabular}{|c|c|}
\hline Generations & Characteristics \\
\hline $\begin{array}{c}\text { Silent Generation } \\
(1927-1945)\end{array}$ & Our grandparents \\
& Republic generation \\
& $7 \%$ in Turkey \\
& Descriptor: Easy-going \\
\hline Baby Boomers & Most members of Turkish Grand National \\
$(1946-1964)$ & Assembly \\
& Prime Minister is a Baby Boomer \\
& $19 \%$ in Turkey \\
& Descriptor: Normative \\
\hline Gen X & Parents of Gezi Park kids \\
& $22 \%$ in Turkey \\
& Descriptor: Competitive \\
\hline Gen Y & 35\% in Turkey $=27$ million \\
$(1980-1999)$ & Descriptor: Creative \\
\hline Gen Z & Crystal Kids \\
$(2000-)$ & Gen Y prepares them \\
& $17 \%$ in Turkey \\
& Descriptor: Over-sensitive \\
\hline
\end{tabular}

\section{Research Method}

In this study, to collect data, an online survey was conducted with the participation of students at Anadolu University, Distance Education Faculty. These students have work experience in various business sectors. Quantitative research method was used. The answers for the following questions have been investigated.

- Does the mean collected from whistleblowing attitude scale and gender variable have a statistically significant difference?

- Does the mean collected from whistleblowing intention scale and gender variable have a statistically significant difference?

In this study, it is aimed to find out whether or not generation has an effect on whistleblowing attitude and whistleblowing intention of students at Anadolu University Distance Education Faculty. To be able to define the relationship between two or more variables and learn a cause and effect relationship, the correlational research method, one of the quantitative research methods, is applied (Büyüköztürk, at al., 2012: 15).

\section{Population and Sample}

The target population of the study consists of students studying at Anadolu University Distance Education faculty from the 2016-2017 Academic Year in Turkey. 
Approximately 1 million 400 thousand students are enrolled at 8 programs offered by Undergraduate Programs in the Faculty of Open Education, 6 programs offered by Faculty of Economics, 39 programs offered by Associate Degree Programs in the Faculty of Open Education, and 5 programs offered by Faculty of Business Administration. 2683 students answered an online survey. Purposive/purposeful sampling technique, which tries to explain natural and social event or phenomena, is applied (Büyüköztürk, at al., 2012: 90).

\section{Limitations}

- This research is limited to the students studying at Anadolu University Distance Education faculty from the 2016-2017 Academic Year in Turkey.

- This research does not focus on a specific business sector, which might be considered as a limitation.

- Only attitude and intention are investigated.

- Type of observed wrongdoing is not asked.

- It is hard to conduct a study with whistleblowers.

\section{Data Collection Tool}

In this study, to collect data, the researchers developed a form called Personal Details Form to define some demographic traits of the participants. To figure out the students' whistleblowing attitude and intention, a 5-point Likert type Whistleblowing as Planned Behavior Scale developed by Park and Blenkinsopp (2009) was used. The scale is based on the Theory of Planned Behavior (TPB) by Ajzen (1991). The scale was translated from English to Turkish then to English, consulted to an expert and piloted before it was conducted.

The survey was applied to students studying at Anatolia University, Distance Education Faculty after the approval of the Ethics Committee. When students logged in to the system with their own user name and password to learn their grades or to reregister, they met the survey link. Clicking the survey link, they filled in the online form on voluntary basis.

\section{Analysis of Data}

In this study, to find out whether there is a relationship between the whistleblowing attitude and generation or whistleblowing intention and generation, t-test technique was applied. SPSS V22 was used for the data analysis.

\section{Findings}

This section includes tables and comments based on the statistical analysis collected by means of the tools stated above.

\section{Does the mean collected from whistleblowing attitude scale and gender variable have a statistically significant difference?}

To answer the question, independent t-test was used to see whether the means of the categories of gender variable show a significant difference or not. Descriptive statistics are as in Table 2. 
Table 2. Descriptive Statistics Regarding the Gender Variable

\begin{tabular}{|c|c|c|c|c|c|}
\hline & Generation & $\mathbf{N}$ & Mean & $\begin{array}{c}\text { Standard } \\
\text { Deviation }\end{array}$ & $\begin{array}{c}\text { Standard } \\
\text { Error }\end{array}$ \\
\hline Attitude & $\mathrm{X}$ & 502 & 38,8825 & 11,23742 &, 50155 \\
\hline & $\mathrm{Y}$ & 2181 & 34,5112 & 12,41553 &, 26573 \\
\hline
\end{tabular}

As seen in Table 2, 502 participants are from Gen X, and the Mean is 38,8825; 2181 participants are from Gen Y, and the Mean is 34,5112. The Mean of Gen X is higher. To figure out whether statistically there is a significant difference, t-test was applied, which is indicated in Table 3.

Table 3. Independent samples t-test results regarding the categories of gender variance

\begin{tabular}{|c|c|c|c|c|c|c|}
\hline & \multicolumn{7}{|c|}{ Levene Variance } \\
& \multicolumn{7}{|l|}{ t-test } & Homogeneity Test \\
\hline & & F & p & t & sd & p \\
\hline Attitude & Homogeneous & 31,498 &, 000 & 7,236 & 2683 &, 000 \\
\hline & $\begin{array}{c}\text { Not } \\
\text { Homogeneous }\end{array}$ & & & 7,701 & 807,138 &, 000 \\
\hline
\end{tabular}

In the analysis, it is seen that the scores of both participants from Gen $\mathrm{X}$ and Gen $\mathrm{Y}$ are not homogeneous $(\mathrm{p}=0,000<0,05)$. That is, the whistleblowing attitude of Gen X's mean is higher.

\section{Does the mean collected from whistleblowing intention scale and gender variable have a statistically significant difference?}

To answer the question, independent t-test was used to see whether the means of the categories of gender variable show a significant difference or not. Descriptive statistics are as in Table 4.

Table 4. Descriptive Statistics Regarding the Gender Variable

\begin{tabular}{|l|c|c|c|c|c|}
\hline & Generation & $\mathbf{N}$ & Mean & $\begin{array}{c}\text { Standard } \\
\text { Deviation }\end{array}$ & $\begin{array}{c}\text { Standard } \\
\text { Error }\end{array}$ \\
\hline Intention & $\mathrm{X}$ & 502 & 27,9482 & 8,54747 &, 38149 \\
\hline & $\mathrm{Y}$ & 2181 & 28,1421 & 9,71573 &, 20804 \\
\hline
\end{tabular}

As seen in Table 4, 502 participants are from Gen X, and the Mean is 27,9482; 2181participants are from Gen Y, and the Mean is 28,1421 . The Mean of Gen Y is higher. To figure out whether statistically there is a significant difference, $\mathrm{t}$ - test was applied, which is indicated in Table 5. 
Table 5. Independent samples t-test results regarding the categories of gender variance

\begin{tabular}{|c|c|c|c|c|c|c|}
\hline & \multicolumn{7}{|l|}{ Levene Variance } \\
& \multicolumn{7}{|l|}{ t-test } & Homogeneity Test \\
\hline & & $\mathbf{F}$ & $\mathbf{p}$ & $\mathbf{t}$ & $\mathbf{S d}$ & $\mathbf{p}$ \\
\hline Intention & Homogeneous & 16,408 &, 000 &,- 412 & 2681 &, 680 \\
\hline & $\begin{array}{c}\text { Not } \\
\text { Homogeneous }\end{array}$ & & &,- 446 & 826,493 &, 656 \\
\hline
\end{tabular}

In the analysis, it is seen that the scores of both participants from Gen $\mathrm{X}$ and Gen $\mathrm{Y}$ are not homogeneous $(0,656>0,05)$. That is, statistically there is not a significant difference between the Means of each generation.

\section{Conclusion}

2683 students with a job experience from Gen X and Gen Y, at Anadolu University, Distance Education Faculty from the 2016-2017 Academic Year, participated in the study. The survey questions, prepared by Park and Blenkinsopp (2009), is based on the TPB by Ajzen (1991). The theory claims that human behavior is guided by three kinds of considerations: attitude toward the behavior which are beliefs about the likely consequences or other attributes of the behavior, subjective norm which refers to beliefs about the normative expectations of other people, and perceived behavioral control which means beliefs about the presence of factors that may further or hinder performance of behavior. When these three elements are in combination, they form a behavioral intention (Ajzen, 2002: 665). Since the theory focuses on one's intention to perform a given behavior, for a possible performance, the intention is expected to be strong. Figure 3 shows what factors have an impact on one's intention (Ajzen, 1991: 181-182).

Figure 3. Theory of Planned Behavior

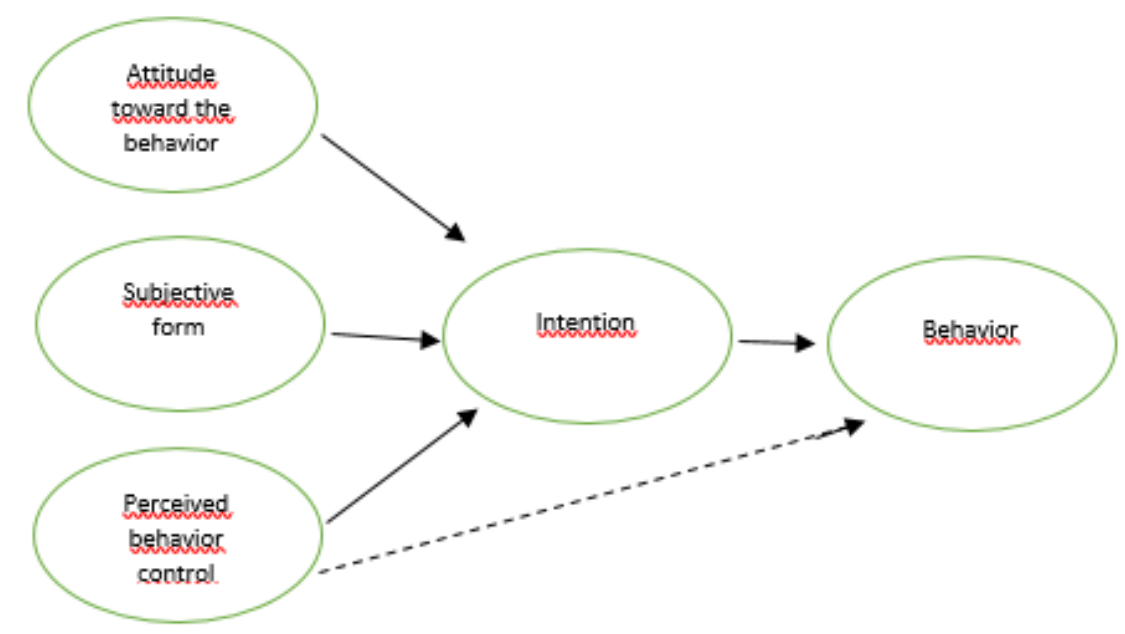

As a result, it is found out that although Gen X students' whistleblowing attitude is higher, they refrain from whistleblowing behavior in terms of intention. However, Gen Ys' intention is higher. Considering conditions in Turkey, the difference might be attributed to the way they were brought 
up, economic, political and technological changes. Gen X students witnessed some socio-political events like oil crisis, economic distress, and right-left conflicts. In that era, women actively started to take part in business life. To have a prosperous life, people preferred to have fewer children. Money became the focal point, and individualism gained importance (Mengi, 2003). Concerns for the future forced this generation to work a lot and save up. Gen Xs are bound to traditional values which naturally make them susceptible to social problems. They show respect to authority. Besides, they are challenging, satisfied, and mistrustful. They value brands. After women started to work, traditional family structure started to be different (Altuntuğ, 2012; Erol \& Öz, 2016; İzmirlioğlu, 2008). On the other hand, Aktan, points out that the 24 January Decisions imposed by the 8th President of Turkish Republic, Turgut Özal, played a crucial role to shape Gen Ys. As a result, the characteristics of Gen Ys, which put human rights and freedom as a baseline and which believe in individualism, are founded (Aktan, 1996). Thus, it can be claimed that, though Gen X's attitude is higher, they might think that whistleblowing is a kind of betrayal.

The result of this study is in a similar vein with the one conducted by Baraz and Şivil in 2017. Based on the study, it was found out that the mean of organizational citizenship behavior of Gen $\mathrm{X}$ is higher than the mean of Gen Y's (Baraz \& Şivil, 2017). The difference might be attributed to the facts stated above. Besides, as Özmen states that behavioral characteristics of generations change as generations get older due to 'age effect', because different generations behave differently in the same period of time. To the researcher, each generation has their own history and background that differentiate them from one another. The difference arises from the sociocultural and political legacy inherited from previous generations (Özmen, 2011). Similarly, according to Wagner and Ruch, older employees value altruism because of thier organizational tenure and life experience (Wagner \& Rush , 2000: 388 ). Since they may have internalized such values, they might think that hepling others is more appreciated, so they might avoid being criticized.

However, based on the 2015 survey conducted by Universum, contrary to the general belief, Gen Ys describe themselves as responsible and loyal employees. Kuran believes that we now need to redefine the term loyalty. Accordingly, regarding generations, it is important to reshape our perceptions, definitions, and expectations, which is vital to use human resources effectively (Kuran, 2015).

Locus of control (LOC) also might be a reason why Gen Xs' intention is lower. LOC includes internal LOC and external LOC. As for Rotter (1966), internal LOC individuals believe themselves to be largely in control of their outcomes, while external LOC individuals believe that fate, luck, or chance determines much of what happens to them (Micheal \& Near, 1985: 8). That is, in this study, Gen Ys may see whistleblowing as a step they must take to control an immoral, illegal or illegitimate activity they cannot approve, while external ones, Gen Xs, may see the same activity as controlled by more powerful others.

Besides, Gen X students' may not want to take any responsibilities due to their age, tenure in the organization, family and the like which might lead to bystander effect. If something immoral, illegal, or illegitimate is witnessed by some people, if person feels less responsibility to report it. Each one may wait upon the others. If there is only one witness, it is s/he could report it. However, when there is a group of witnesses, this would allow diffusion of responsibility and everyone expects one another to do something (Latané \& Darley, 1970: 342).

The type of observed wrongdoing is significantly related to participants' response. In this study, they are not provided with a scenario, so they do not know whether the wrongdoing involves mismanagement, sexual harassment, or legal violation or not. 
A study was conducted at a military base in the USA, and it was found out that employees are more prone to blowing the whistle when they observe mismanagement, sexual harassment or legal violations than stealing, waste, safety problems, or discrimination. Below are the types of wrongdoing (Near, at al, 2004: 226-227):

Table 6. Types of Wrongdoing (Near, at al, 2004: 226-227)

\begin{tabular}{|c|l|}
\hline Type & \multicolumn{1}{|c|}{ Focal Wrongdoing } \\
\hline $\mathbf{1 0 \%}$ & $\begin{array}{l}\text { a) stealing of federal funds, } \\
\text { b) stealing of federal property, } \\
\text { c) accepting bribes/kickbacks, } \\
\text { d) use of official position for personal benefit, } \\
\text { e) unfair advantage to contractor, and } \\
\text { f) employee abuse of office }\end{array}$ \\
\hline $\begin{array}{c}\text { Waste } \\
\mathbf{4 4 \%}\end{array}$ & $\begin{array}{l}\text { a) waste by ineligible people receiving benefits } \\
\text { b) waste by a badly managed program; and } \\
\text { c) waste of organizational assets }\end{array}$ \\
\hline $\begin{array}{c}\text { Mismanagement } \\
\mathbf{1 1 \%}\end{array}$ & $\begin{array}{l}\text { a) management's cover-up of poor performance and } \\
\text { b) management's making false projections } \\
\text { performance }\end{array}$ \\
\hline $\begin{array}{c}\text { Safety problems } \\
\mathbf{8 \%}\end{array}$ & $\begin{array}{l}\text { a) unsafe or non-compliant products and } \\
\text { b) unsafe working condition }\end{array}$ \\
\hline $\mathbf{8 \%}$ & $\begin{array}{l}\text { a) unwelcome sexual advances/requests for sexual } \\
\text { favors and } \\
\text { b) verbal/ physical contact of sexual nature }\end{array}$ \\
\hline $\begin{array}{c}\text { Unfair } \\
\text { discrimination }\end{array}$ & race, sex, religion etc. \\
\hline $\begin{array}{l}\text { Oth\% } \\
\text { violation of law }\end{array}$ & observing other legal violations \\
\hline $\mathbf{7 \%}$ & \\
\hline
\end{tabular}

Besides, there are some examples which make the observers believe that in spite of the enforced laws, not much is done. For instance, a 1976 study of OSHA showed only $20 \%$ of the complaints filed that year were considered valid. About half of these claims were settled out of court, and of the 60 claims taken to court, only one won. Besides, in the late 1990s, the U.S. Equal Employment Opportunity Commission (EEOC) dismissed 90\% of employees' charges. Moreover, in 2006, "reasonable cause" was found in only $5.3 \%$ of the more than 75,000 charges of discrimination filed with the EEOC (Miceli vd., 2008: 21). All these deter the observers from blowing the whistle.

Another reason why the observers do not put it into action is because of its costs. One of the major examples of wrongdoing was Roche case in Turkey. Veysi Mungan, the former senior executive, found out that the company was deceiving the state-run Social Security Agency (SGK). He did internal whistleblowing in 2003 but then had to apply to external channel. He has had to suffer from unemployment, threats, discriminations, and many court cases since then (Başaran, 2010; Algan, 2016). Observants who do not want to experience such things might prefer to stay silent.

It is recommended that the Turkish government should enforce organizations to develop some policies, which guide observers to follow some steps and which warrant that there will not be any retaliations because Gen Ys will be more active in business life soon. Additionally, since managements in organizations are supposed to protect their stakeholders and shareholders' rights, 
and not to lose face, especially multi-partnered corporations should take precautions to encourage internal whistleblowing. It should also be considered that Gen Ys are more comfortable when they use the technology, so a training program might be prepared for employees. Cases like Enron set a good example why an internal system is required. As it is known, Enron's devastating effects are still prevalent, and although SOX has applied a number of sanctions, employees participation will definitely make the organizational culture stronger.

As stated earlier. Gen Ys will be more populous very soon. To the 2016 report by TÜIK, total population compared to the previous year increased 1.073.818 and reached 79.814.871. Total population consisted of $27.7 \%$ of $0-14$ age group, $68 \%$ of $15-64$ age group, and $8 \%$ of 65 plus age group (TUIK, 2016). Considering the data, it is suggested that habits and expectations of the active population should be taken into account, and internal whistleblowing should be encouraged by organizations. 


\section{REFERENCES}

Çiftçi, B. (2017). Türkiye'de Toplumsal Kültürün Örgütlerde İhbarcılık Üzerine Etkisi: Hofstede'in Kültürel Boyutlar Teorisi Bağlamında Bir Değerlendirme. International Journal of Academic Value Studies (Javstudies), 3(10), 147-166.

Özmen, F. A. (2011). Alevi Gençliğinin Siyasi ve Sosyo-Kültürel Kimlik Mücadelesi I. Alternatif Politika, 3(1), 31-54.

ACFE. (2004). 2004 Report to the Nation on Occupational Fraud and Abuse. AFCE.

ACFE. (2016). Report to the Nations on Occupational Fraud and Abuse.

Ajzen, I. (1991). The theory of planned behavior. Organizational Behavior and Human Decision Processes, 50(2), 179-211. doi:http://dx.doi.org/10.1016/0749-5978(91)90020-T

Ajzen, I. (2002). Perceived Behavioral Control, Self-Efficacy, Locus of Control, and the Theory of Planned Behavior. Journal of Applied Social Psychology, 32(4), 665-683.

Aktan, C. C. (1996). Turgut Özal'ın Değişim Modeli ve Değişime Karşı Direnen Güçlerin Tahlili. Türkiye Günlügü Dergisi, 15-32.

Aktan, C. C. (2008). Meslek Ahlakı ve Sosyal Sorumluluk. Iş̧ Ahlakı Dergisi, 1(1), 99-121.

Algan, E. (2016, 03 12). T24. 07 14, 2017 tarihinde http://t24.com.tr/yazarlar/emine-algan/rochedavasi-vicdanin-ve-durustlugun-zaferi,14087 adresinden alınd1

Altuntuğ, N. (2012). Kuşaktan Kuşağa Tüketim Olgusu ve Geleceğin Tüketici Profili. Organizasyon ve Yönetim Bilimleri Dergisi, 4(1), 203-212.

Arslan, A., \& Staub, S. (2015). Kuşak Teorisi ve İç Girişimcilik Üzerine Bir Araştırma. KA $\ddot{U}$ IIIBF Dergisi, 6(11), 1-24.

Ağlargöz, O. (2013). Stratejik Yönetim ve Kurumsal Yönetişim. K. Mirze, S. Besler, A. Şakar, M. Barca, D. Paşaoğlu, O. Ağlargöz, \& F. Dalyan içinde, Stratejik Yönetim II. Anadolu Üniversitesi.

Bülbül, İ. (2005). Türkiye'de İkinci Dünya Savaşı Döneminde Savaşın Sosyal Yaşam Üzerinde Etkileri. İstanbul Üniversitesi Atatürk İlke ve İnkılapları Estitüsü, Yayınlanmamış Doktora Tezi.

Büyüköztürk, Ş., Çakmak, E. K., Akgün, Ö. E., Karadeniz, Ş., \& Demirel, F. (2012). Bilimsel Araştırma Yöntemleri. Ankara: Pegem Akademi.

Başaran, E. (2010, 06 10). Hürriyet.com.tr. 14 07, 2017 tarihinde Gündem: http://www.hurriyet.com.tr/devlete-5-2-milyon-kazandirdi-issiz-kaldi-14740826 adresinden alınd 1

Baltac1, A. (2017). Bilgi Uçurma: Kavram ve Kuramsal Temeller. Muş Alparslan Üniversitesi Sosyal Bilimler Dergisi, 5(2), 397-423.

Baraz, A. B., \& Şivil, H. (2017). The Relationship between Demographic Variables Between Gen X and Gen Y Students and Organizational Citizenship Behavior. Journal of Youth Researches, 5(13), 109-126.

Beyhan, M. A. (1999). II. Abdülhanid Döneminde Hafiyye Teşkilatı ve Jurnaller. İlmî Araștırmalar : Dil, Edebiyat, Tarih Incelemeleri, 8, 65-83.

BIMMER. (tarih yok). BIMER. 07 24, 2017 tarihinde https://www.bimer.gov.tr/ adresinden alınd1

Brief, A. P., \& Motowidlo, S. J. (1986). Prosocial Organizational Behaviors. Academy of Management Review, 44(4), 710-725.

BSI. (2004). Küresel Ihbar Politikast ve. https://www.bsigroup.com/LocalFiles/trTR/ihbar\%20Politikasi.pdf adresinden alındı

CIMER. (tarih yok). CIMER. 12 06, 2017 tarihinde http://www.devlette.com/cumhurbaskanligiiletisim-merkezi-cimer-sikayet-basvurusu/ adresinden alındı

Danışman, S. A. (2012). Sosyal Sorumluluk Olarak İhbarcılık. Işs Ahlakı Dergisi, 5(2), 227- 233.

DeGeorge, R. T. (1999). Business Ethics (5 b.). New Jersey: Prentice Hall.

Devine, T., \& Maassarani, T. F. (2011). The Corporate Whistleblower's Survival Guide: A Handbook for Committing the Truth. San Francisco: Berrett-Koehler Publishers.

Dozier, J. B., \& Miceli, M. P. (1985). Potential Predictors of Whistle-Blowing: A Prosocial Behavior Perspective. Academy of Management Review, 10(4), 823-836. 
Doğan, A. N. (2009, 11 07). Yakın Tarihimizin Utanç Veren Olayları: 27 Mayıs Darbesi,1960. Milliyet. 04 22, 2017 tarihinde http://blog.milliyet.com.tr/yakin-tarihimizin-utanc-verenolaylari--27-mayis-darbesi--1960/Blog/?BlogNo=212490 adresinden alınd 1

Erkmen, T. (2014, 11 25). Kişisel Itibar ve Whistleblowing. 07 21, 2017 tarihinde Slideshare: https://www.slideshare.net/itibarenstitusu/kiisel-itibar-ve-whistleblowing-turhanerkmen adresinden alınd 1

Erol, F., \& Öz, M. (2016, 01 30). A Study on the Increasing Retro Trends of Gereration Y. International Journal of Social Sciences, 41(1), 53-59.

Gaudet, R. (2016). Whistleblowing: How Millennials' Desire for Transparency Affects National Security: Baker School Project. The University of Tennessee, USA.

Grant, C. (2002). Whistle Blowers: Saints of Secular Culture. Journal of Business Ethics, 39, 391399.

Hür, A. (2015, 08 16). Her daim itibarlı (!) meslek: Jurnalcilik. Radikal. 03 14, 2018 tarihinde http://www.radikal.com.tr/yazarlar/ayse-hur/her-daim-itibarli-meslek-jurnalcilik1416114/ adresinden alındı

Haydaroğlu, İ. (1997). II. Abdülhamit'in Hafiye Teşkilatı Hakkında Bir Risale. Ankara Üniversitesi Dil Tarih ve Coğrafya Fakültesi, Tarih Araştırmaları Dergisi, 109-133.

Hersh, M. (2002). Whistleblowers- Heroes or Traitor?: Individual and Collective Responsibility for Ethical Behavior. Annual Reviews in Control(26), 243-262.

Hoffman , M. W., \& Schwartz, M. S. (2015). The Morality of Whistleblowing: A Commentary on Richard T. De George. Journal of Business Ethics, 771-781.

İzmirlioğlu, K. (2008). Konumlandırmada Kuşak Analizi Yardımıyla Tüketici Algılarının Tespiti: Türk Otomotiv Sektöründe Bir Uygulama. Muğla: Muğla Üniversitesi, Sosyal Bilimler Enstitüsü Yayınlanmamış Yüksek Lisans Tezi.

Jubb, P. B. (1999). Whistleblowing: A Restrictive Definition and Interpretation. Journal of Business Ethics, 77-94.

KPMG Forensic Fraud Survey. (2003). Fraud Survey. Montvale: KPMG.

Kuran, E. (2013, 06 09). Yaşasın Y Kuşağı. (A. Arman, Röportaj Yapan) 04 20, 2017 tarihinde http://www.hurriyet.com.tr/yasasin-y-kusagi-23465715 adresinden alınd 1

Kuran, E. (2015, Eylül). HBR Türkiye. https://hbrturkiye.com/dergi/turkiye-nin-y-kusagisirketlerden-ne-istiyor adresinden alındı

Kurumsal Yönetim. (2017). Sermaye Piyasası Lisanslama Sicil ve Eğitim Kuruluşu A.Ş.

Latané, B., \& Darley, J. M. (1970). The Unresponsive Bystander. New York: Appleton-CenturyCrofts.

Leeds, R. (1963). Altruism and The Norm of Giving. Merrill-Palmer Quarterly of Behavior and Development, 9(3), 229-240.

Mengi, Z. (2003). KIGEM. http://www.kigem.com/is-basarisinda-kusak-farki.html adresinden alınd 1

Miceli , M. P., \& Near, J. P. (1992). Blowing the whistle: The organizational and legal implications for companies and employees. Lexington Books.

Miceli , M. P., Near, J. P., \& Schwenk, C. R. (1991). Who Blows the Whistle and Why? Industrial and Labor Relations Review, 1(45), 113-130.

Miceli, M. P., \& Dozier, J. B. (1985). Potential Predictors of Whistle-Blowing : A Prosocial Behavior Perspective. Academy of Management Review, 4(10), 823-836.

Miceli, M. P., \& Near, J. P. (1985). Organizational Dissidence : The Case of Whistle-Blowing. Journal of Business Ethics.

Miceli, M. P., \& Near, J. P. (1992). Blowing the Whistle: The Organizational and Legal Implications for Companies and Employees. Lexington Books.

Miceli, M. P., Near, J. P., \& Dworkin, T. M. (2008). Whistle-blowing in Organizations. Taylor \& Francis Group, LLC.

Near, J. P., \& Marcia, M. P. (1996). Whistle-Blowing: Myth and Reality. Journal of Management, 22(3), 507-526. 
Near, J. P., Rehg, M. T., Van Scotter, J. R., \& Miceli, M. P. (2004). Does Type of Wrongdoing Affect the Whistleblowing Process? Business Ethics Quarterly, 14(2), 219-242.

NWC. (tarih yok). 10 22, 2017 tarihinde National Whistleblowing Center: http://www.whistleblowers.org/ adresinden alınd1

Organ, D. W., Podsakoff, P. M., \& MacKenzie, S. B. (2006). Organizational Citizenship Behavior: Its Nature, Antecedents, and Consequences. Thousand Oaks: SAGE Publications, Inc. doi: http://dx.doi.org/10.4135/9781452231082.n2

Orr, L. H. (2001). Is Whistle-Blowing the Sama as Informer? Business \& Society Review(39), 417.

Park, H., Blenkinsopp, J., Oktem, M. K., \& Omurgonulsen, U. (2008). Cultural orientation and attitudes towards different forms of whistleblowing: A comperasion of South Korea, Turkey and the UK, 82 (4). Journal of Business Ethics, 929-939.

Sayğan, S., \& Bedük, A. (2013). Ahlaki Olmayan Davranışların Duyurulması (Whistleblowing) ve Etik İklimi İlişkisi Üzerine Bir Uygulama, 28(1). Dokuz Eylül Üniversitesi İktisadi ve İdari Bilimler Fakültesi Dergisi , 1-23.

Seifert, D. L. (2006). The Influence of Organizational Justice on the Perceived Likelihood of Whistleblowing. Washington State University.

Stroman, S. H., \& Duff, E. R. (2012, 07 27). The Latchkey Child: Whose Responsibility? Childhood Education, 76-79. http://dx.doi.org/10.1080/00094056.1982.10520550 adresinden alınd 1

Tekin, A. G. (2003). Kurumsal Yönetişim (Corporate Governance), Kuvvetler Ayrıllı̆ı İlkesi ve Denetimden Sorumlu Komiteler. Ekonomistler Bülteni. 12 04, 2017 tarihinde http://www.angelfire.com/ok4/aligunertekin/200305CGDSKomiteler.pdf adresinden alınd 1

TÜSİAD. (tarih yok). OECD Guidelines on Corporate Governance of State Owned Enterprises. 012019 tarihinde TÜSİAD: https://tusiad.org/en/reports/item/3610-oecd-guidelines-oncorporate-governance-of-state-owned-enterprises adresinden alınd

Toruntay, H. (2011). Takım Rolleri Çalışması: X ve Y Kuşağı Üzerine Karşılaştırmalı Bir Çalışma. Ístanbul Üniversitesi, Sosyal Bilimler Enstitüsü .

TUIK. (2016). Nüfus ve Demografi. 04 20, 2017 tarihinde Konularına Göre İstatistikler: http://www.tuik.gov.tr/Start.do adresinden alınd1

Uğur, H. (2013). Suçların İhbarı ve İhbarcıların Korunması. TBB Dergisi, 108, 383-406.

Vandekerckhove, W. (2006). Whistleblowing and Organizational Social Responsibility: A Global Assessment, 7-8. Ashgate Publishing Limited.

Verschoor, C. C. (2010). We need more whistleblowers. Stratejic Finance.

Wagner, S. L., \& Rush , C. M. (2000). Altruistic Organizational Citizenship Behavior:Context, Disposition, and Age. The Journal of Social Psychology, 140(3), 379-391. 